\title{
Characterization and anti-staphylococcal activity of the essential oil from Turnera subulata Sm.
}

\author{
FERNANDES, M.G.'; GOMES, R.A.'; BRITO-FILHO, S.G.'; SILVA-FILHO, R.N.'; AGRA, M.F.'; FALCÃO-SILVA, \\ V.S.2; SIQUEIRA-JUNIOR, J.P.2; VIEIRA, M.A.R. ${ }^{3 ;}$ MARQUES, M.O.M. ${ }^{3 ;}$ SOUZA, M.F.V. ${ }^{*}$ \\ 'Post Graduation in Natural Products and Synthetic Bioactives - Campus I, Federal University of Paraíba, João \\ Pessoa-PB, Brasil. ${ }^{2}$ Department of Molecular Biology, Federal University of Paraíba, Campus I, 58059-900 \\ João Pessoa-PB, Brazil ${ }^{3}$ Center of R \& D of Plant Genetic Resources, Agronomical Institute, CP 28, 13001-970 \\ Campinas-SP, Brazil. * mfvanderlei@Itf.ufpb.br
}

\begin{abstract}
RESUMO: O presente estudo é pioneiro em analisar a composição química dos óleos essenciais das partes aéreas de Turnera subulata $\mathrm{Sm}$. e sua atividade antibacteriana frente à Staphylococcus aureus resistentes a antibióticos. As partes aéreas da planta foram secas em estufa, pulverizadas em moinho mecânico e submetidas à hidrodestilaçao em aparato tipo Clevenger. A composição dos óleos essenciais foi analisada por cromatografia gasosa acoplada a espectrometria de massas (CG-EM), e a identificação realizada por comparação dos espectros de massas com a biblioteca do CG-EM e índices de retenção. A atividade antimicrobiana do óleo essencial foi avaliada usando o método de diluição em caldo, em concentrações que variaram de $3.125 \mu \mathrm{g} / \mathrm{mL}$ to $3200 \mu \mathrm{g} / \mathrm{mL}$. Foi possível identificar 45 substâncias $(92,1 \%)$ do óleo essencial, sendo os componentes majoritários: trans-cariofileno $(6,7 \%)$, citronelol $(5,6 \%)$, espatulenol $(5,3 \%)$, a-cadinol (4,3\%), n-tricosano $(4,3 \%)$, geraniol $(4,1 \%)$ e trans-geranilacetona $(3,7 \%)$, n-pentacosano $(3,5 \%)$, globulol $(3,4 \%)$ e óxido de cariofileno $(3,2 \%)$. O óleo essencial de $T$. subulata $\mathrm{Sm}$. mostrou atividade antibacteriana eficaz para as várias cepas de $S$. aureus testadas, com valores de CIM entre $25 \mu \mathrm{g} / \mathrm{mL}$ e $1600 \mu \mathrm{g} / \mathrm{mL}$. O estudo do óleo essencial de Turnera subulata Sm. evidenciou sua complexa mistura, contendo várias classes de substâncias, tendo os sesquiterpenos como constituintes majoritários seguido dos monoterpenos, e mostrou significativa atividade antibacteriana frente as cepas testadas.
\end{abstract}

Palavras-chave: Turnera subulata, CG-EM, Turneraceae, óleo essencial, atividade antiestafilocócica

\begin{abstract}
Characterization and anti-staphylococcal activity of the essential oil from Turnera subulata $\mathrm{Sm}$. The present study is pioneer in analyzing the chemical composition of the essential oil from aerial parts of Turnera subulata Sm. and evaluates their antibacterial activity against a panel of drug-resistant strains of Staphylococcus aureus. The aerial parts were kiln-dried and then powdered in mechanical mill, and was subjected to hydrodistillation in a Clevenger-type apparatus. The components were analyzed using a mass spectrometrycoupled gas chromatography (GC-MS), and the identification of substances was performed by comparison of the mass spectra obtained with the mass spectra of the database of the GC-MS and retention indices. The essential oil was evaluated using the method of broth dilution at concentrations ranging from $3.125 \mu \mathrm{g} / \mathrm{mL}$ to $3200 \mu \mathrm{g} / \mathrm{mL}$. It was possible to identify 45 substances $(92.1 \%)$ of the essential oils, and the major components were trans-caryophyllene $(6.7 \%)$, citronellol (5.6\%), sphatulenol (5.3\%), a-cadinol (4.3\%), n-tricosano $(4.3 \%)$, geraniol $(4.1 \%)$ and transgeranilacetone (3.7\%), n-pentacosano (3.5\%), globulol (3.4\%), caryophyllene oxide (3.2\%). The essential oil of $T$. subulata $\mathrm{Sm}$. showed effective antibacterial activity for the various strains of $S$. aureus tested, with the MIC values between $25 \mu \mathrm{g} / \mathrm{mL}$ and $1600 \mu \mathrm{g} / \mathrm{mL}$. The study of the essential oil of Turnera subulata Sm. showed that it consists of a complex mixture of several classes of compounds having the sesquiterpenes as major constituents followed by monoterpenes, and showed an antibacterial activity significant front the strains tested.
\end{abstract}

Keywords: Turnera subulata, GC-MS, Turneraceae, essential oils, antistaphylococcal activity

Recebido para publicação em 02/04/2013

Aceito para publicação em 26/03/2014

10.1590/1983-084X/13_011

Rev. Bras. PI. Med., Campinas, v.16, n.3, p.534-538, 2014. 


\section{INTRODUCTION}

Essential oils are volatile elements contained in many vegetable organs, and are related to several functions necessary for the plant survival, also has great importance in the defense against pathogens (Siqui et al., 2000). Researchers have been interested in biologically active compounds isolated from plant species for the elimination of pathogenic microorganisms because of the resistance that microorganisms have built against antibiotics (Essawi, 2000).

The bacterial resistance to multiple antibiotics has increased throughout the decades, making conventional antibiotics impotent against the bacterial resistance, such as Staphylococcus aureus (lowy, 2003), which culminates in the necessity for new drugs discovery. The essential oils have been used in folk medicine for decades as antimicrobial (Fisher and Phillips, 2008). Thus, natural products of plant origin are a rich source of new antimicrobials (Lewis \& Ausubel, 2006).

Turnera subulata $\mathrm{Sm}$, popularly known as "chanana" or "flor-do-Guarujá", is a member of the family Turneraceae (Gonzalez and Arbo, 2005), which consists of 10 genera and about 200 species that have distribution from North to South America, and in Africa, including Madagascar and the Mascarene Islands (Arbo, 2007).

In Brazil the family Turneraceae is represented by two genera, Piriqueta and Turnera, being this the most representative in the country having about 140 species (Arbo, 2008). According to Arbo (2007), Brazil holds the top number of species, the highest number of endemics being found in the mountains of the states of Bahia, Goiás and Minas Gerais. The genus is characterized by the presence of terpenoids, like mono and sesquiterpenes, flavonoids, steroids, benzenoids, alkaloids and lipids (Barbosa et al., 2007).

The roots of Turnera chamaedrifolia Cambess. and Turnera subulata Sm. are sold in street markets of the State of Paraíba and used in folk medicine (in the form of tea) in the treatment of amenorrhea, dysmenorrhea and as an abortifacient (Barbosa et al., 2007).

Previous studies have defined the many constituents of the essential oil of several species of Turnera, including T. diffusa, T. aphrodisiaca and T. brasiliensis (Kumar et al., 2006; Maia et al., 2007).

It was observed that the phytochemical studies have mainly focused on the characterization of the extracts, with few reports on the composition of essential oils. The present study is pioneer in analyzing the chemical composition of the essential oil from aerial parts of Turnera subulata Sm. The essential oil was also evaluated for antibacterial activity against a panel of drug-resistant strains of
Staphylococcus aureus.

\section{Experimental}

Plant material: The aerial parts of Turnera subulata $\mathrm{Sm}$. was collected in the University campus, in João Pessoa, the coastal region of Paraíba, Brazil, in August 2008, and indentified by one of the authors (M.F.A.). A voucher specimen (Agra \& Barbosa 6273) was deposited at the herbarium Prof. Lauro Pires Xavier (JPB), Federal University of Paraíba.

The aerial parts were kiln-dried, with air circulating system, at $40^{\circ} \mathrm{C}$ for a period of 48 hours, and then powdered in mechanical mill. $427.7 \mathrm{~g}$ of plant material was subjected to hydrodistillation in a Clevenger-type apparatus for 3 hours. For the analysis, $1 \mu \mathrm{L}$ of the essential oil was diluted in $1 \mathrm{~mL}$ of ethyl acetate (chromatographic degree).

Analysis of the essential oils: The components of the essential oil were analyzed using a gas chromatograph coupled to mass spectroscopy (GC-MS, Shimadzu QP-5000, Japão) equipped with a capillary column OV-5 (Ohio Valley Specialty Chemical, Inc.; $30.0 \mathrm{~m} \times 0.25 \mathrm{~mm} \times 0.25 \mathrm{~m}$ ). The column temperature was programmed from $60^{\circ} \mathrm{C}$ to $280^{\circ} \mathrm{C}$, at a rate of $3^{\circ} \mathrm{C} / \mathrm{min}$. The temperatures of the injector and detector were $220^{\circ} \mathrm{C}$ and $230^{\circ} \mathrm{C}$, respectively. Helium was used as the carrier gas, at a flow rate of $1 \mathrm{~mL} / \mathrm{min}$. The injection of the oil was manually, $1 \mu \mathrm{L}$ the solution, with split of $1: 10$. The mass spectra were obtained with electron impact (EI) of $70 \mathrm{eV}$.

Identification and quantification the components of the oil were identified by comparison of their retention indices (determined in relation to an homologous series of n-alkanes) with those of pure standards or as reported in the literature (Adams, 1995). Comparision of fragmentation patterns in the MS with those stored on the CG-MS databases (NIST 62) was also performed. The percentages of each component were reported as raw percentages without standardization.

Bacterial strains: Three strains possessing efflux pumps for resistance to fluoroquinolones, macrolides and tetracycline, vis.SA-1199B, RN4224 (pUL5054) and IS-58, respectively (Gibbons et al., 2003; Falcão-Silva et al., 2009), and five strains resistant to methicillin and to aminoglycosides (Freitas et al., 1999). The strain ATCC 25923 was used as reference control. The strains, were maintained in blood Agar base (Laboratórios Difco Ltda., Brazil) slants, and prior to use, the cells were grown overnight at $37^{\circ} \mathrm{C}$ in brain heart infusion broth (BHI - Laboratórios Difco Ltda., Brazil).

Antibacterial assay: The stock solution of the essential oil was prepared in DMSO which 
at its highest final concentration after dilution in the broth $(4 \%)$ caused no inhibition of bacterial growth. The minimum inhibitory concentration (MIC) of the essential oil was determined in $\mathrm{BHI}$ by the microdilution assay (CSLI, 2005) using a suspension of ca. $10^{5} \mathrm{cfu} / \mathrm{mL}$ and an essential oil concentration range of $3200-3.125 \mu \mathrm{g} / \mathrm{mL}$ (two-fold serial dilutions). The MIC, determined in duplicate, is defined as the lowest concentration at which no growth is observed.

\section{RESULTS AND DISCUSSION}

Through the analysis of the essential oil of Turnera subulata in GC-MS it was possible to identify 45 substances, representing $92.1 \%$ of the total essential oil (Table 1 ).

It was observed that main component of the essential oil of $T$. subulata trans-caryophyllene representing about $6.7 \%$ of the total chemical composition, followed by citronellol $(5.6 \%)$, spathulenol (5.2\%), a-cadinol (4.3\%), n-tricosane $(4,3 \%)$, geraniol $(4.1 \%)$, trans-geranilacetone $(3.7 \%)$, n-pentacosane (3,5\%), globulol $(3.4 \%)$ and caryophyllene oxide $(3.2 \%)$ (Table 1$)$.

It can be verified that this essential oil is composed of a complex mixture of several kinds of substances, comprising an alcohol, five monoterpenes, twenty-three sesquiterpenes, eight hydrocarbons, four fatty acids, one ester, two ketones and one aldehyde.

It is important to stand out that, in the same way as reported for Turnera brasiliensis (Maia et al., 2007), this study with the essential oil of Turnera subulata Sm, showed the presence of $(E)$-caryophyllene $(6.7 \%)$, a-humulene $(1.3 \%)$, and $\alpha$-selinene $(2.0 \%)$. On the other hand, when compared the studies of the essential oil extracted from the leaves of $T$. diffusa and $T$. aphrodisiaca (Kumar et al., 2006; Maia et al., 2007), with T. subulata (Table 1), this studies did not exhibited any results in common. The essential oil extracted from the leaves of $T$. diffusa showed the presence of monoterpenes 1,8-cineole, p-cymene, a-pinene, $\beta$-pinene (Antônio, 1996). The oil from T. aphrodisiaca showed the presence of $\alpha$-pinene, $\beta$-pinene, p-cymene, 1,8-cineole and $\beta$-sitosterol (Kumar et al., 2006).

Studies with two samples of essential oils of Turnera brasiliensis predominantly showed (E)-caryophyllene $(23.8 \%$ and $3.7 \%$, respectively), a-humulene (22.0\% and traces), alloaromadendrene $(1.3 \%$ and $42.4 \%), \beta$-selinene (5.8\% and $12.2 \%$ ) and $\alpha$-selinene (15.2\% and 24.4\%) (Maia et al., 2007).

A study with Turnera ulmifolia showed that its essential oil had excellent antifungal activity against dermatophyte species, inhibiting $100 \%$ of
Table 1. Chemical composition (\%) of the essential oil of Turnera subulata Sm.

\begin{tabular}{|c|c|c|c|}
\hline SUBSTANCES & $\%$ & IR exp & IR lit \\
\hline \multicolumn{4}{|l|}{ ALCOHOLS } \\
\hline 1-octen-3-ol & 0.6 & 976 & 978 \\
\hline Total & 0.6 & - & - \\
\hline \multicolumn{4}{|l|}{ MONOTERPENES } \\
\hline linalool & 2.1 & 1096 & 1098 \\
\hline citronellol & 5.6 & 1224 & 1228 \\
\hline geraniol & 4.1 & 1250 & 1255 \\
\hline trans-mirtanol & 1.1 & 1254 & 1259 \\
\hline trans-geranilacetone & 3.7 & 1447 & 1453 \\
\hline Total & 16.6 & & \\
\hline \multicolumn{4}{|l|}{ SESQUITERPENES } \\
\hline$\alpha$-copaene & 0.8 & 1374 & 1376 \\
\hline$\beta$-elemene & 1.3 & 1390 & 1391 \\
\hline trans-caryophyllene & 6.7 & 1417 & 1418 \\
\hline a-humulene & 1.3 & 1451 & 1454 \\
\hline trans- $\beta$-farnesene & 0.8 & 1455 & 1458 \\
\hline Y-muurolene & 0.6 & 1474 & 1477 \\
\hline germacrene - D & 1.0 & 1478 & 1480 \\
\hline$\alpha$-selinene & 2.0 & 1494 & 1494 \\
\hline a-muurolene & 0.6 & 1498 & 1499 \\
\hline$\delta$-cadinene & 1.3 & 1521 & 1524 \\
\hline occidentalol & 0.5 & 1545 & 1548 \\
\hline trans-nerolidol & 2.3 & 1560 & 1564 \\
\hline spathulenol & 5.2 & 1574 & 1576 \\
\hline Caryophyllene oxide & 3.2 & 1579 & 1581 \\
\hline globulol & 3.4 & 1580 & 1583 \\
\hline 1,10-di-epi-cubenol & 1.4 & 1611 & 1614 \\
\hline 1-epi-cubenol & 0.9 & 1624 & 1627 \\
\hline epi-a-cadinol & 1.2 & 1637 & 1640 \\
\hline a-muurolol & 1.0 & 1642 & 1645 \\
\hline$\beta$ - eudesmol & 0.7 & 1645 & 1649 \\
\hline a-cadinol & 4.3 & 1650 & 1653 \\
\hline 14-hydroxy-9-epi-ß-caryophyllene & 0.6 & 1663 & 1664 \\
\hline Unidentified sesquiterpenes & 9.5 & - & - \\
\hline Total & 50.6 & - & - \\
\hline \multicolumn{4}{|l|}{ HIDROCARBONS } \\
\hline n-hexadecane & 1.1 & 1630 & 1600 \\
\hline n-tetradecane & 0.6 & 1402 & 1399 \\
\hline n-heneicosane & 1.5 & 2102 & - \\
\hline n-tricosane & 4.3 & 2302 & 2300 \\
\hline n-tetracosane & 0.6 & 2401 & 2400 \\
\hline
\end{tabular}

continua... 
Table 1. Chemical composition (\%) of the essential oil of Turnera subulata Sm.

\begin{tabular}{|c|c|c|c|}
\hline \multicolumn{4}{|c|}{ continuação.. } \\
\hline n-pentacosane & 3.5 & 2502 & 2500 \\
\hline n-hexacosane & 1.3 & 2602 & - \\
\hline n-heptacosane & 0.5 & - & - \\
\hline Total & 11.8 & - & - \\
\hline \multicolumn{4}{|l|}{ FATTY ACIDS } \\
\hline Palmitoleic acid & 2.2 & 1964 & - \\
\hline Palmitic acid & 1.4 & 1964 & - \\
\hline Linoleic acid & 0.9 & 2157 & - \\
\hline Linolenic acid & 0.8 & 2163 & - \\
\hline Total & 5.3 & - & - \\
\hline \multicolumn{4}{|l|}{ ESTERS } \\
\hline Ethyl palmitate & 0.9 & 1992 & - \\
\hline Total & 0.9 & - & - \\
\hline \multicolumn{4}{|l|}{ ALDEHYDES } \\
\hline octadecanal & 2.0 & 1710 & - \\
\hline Total & 2.0 & - & - \\
\hline \multicolumn{4}{|l|}{ KETONES } \\
\hline 2-pentadecanone & 0.5 & 1695 & - \\
\hline 2-octadecanone & 1.7 & 1842 & - \\
\hline Total & 2.3 & - & - \\
\hline \multicolumn{4}{|c|}{ OTHERS COMPONENTS } \\
\hline$\beta$-trans-ionone & 2.1 & 1480 & 1488 \\
\hline TOTAL & 92,1 & & \\
\hline
\end{tabular}

IR: Retention Indices

the strains tested (Lima et al., 2000).

MIC values of the essential oil of Turnera subulata $\mathrm{Sm}$ against strains of $\mathrm{S}$ aureus are presented in Table 2. Essential oils are potential sources of new antimicrobial compounds especially against bacterial pathogens (Prabuseenivasan et al., 2006).

An important characteristic of the essential oil is its hydrophobicity, which allows them to change the lipids in the cell membrane of bacteria, destructuring and making them more permeable to ions and other molecules that may lead to cell death (Sikkema et al., 1994).

\section{CONCLUSION}

The essential oil of leaves of $T$. subulata is constituted of complex mixture of different kinds of substances: alcohols $(0,6 \%)$, monoterpenes $(16,6 \%)$, sesquiterpenes $(50,6 \%)$, hydrocarbons $(11,8 \%)$, fatty acids $(5,3 \%)$, esters $(0,9 \%)$, aldehydes $(2,0)$ and ketones $(2,3 \%)$. The sesquiterpene transcaryophyllene $(6,7 \%)$ predominate in essential oil.
Table 2. Anti-staphylococcal activity of the essential oil of Turnera subulata Sm

\begin{tabular}{cc}
\hline Strains & $\mathrm{MIC}$ \\
\hline ATCC 25923 & $200 \mu \mathrm{g} / \mathrm{mL}$ \\
\hline IS-58* & $800 \mu \mathrm{g} / \mathrm{mL}$ \\
\hline RN-4220* & $800 \mu \mathrm{g} / \mathrm{mL}$ \\
\hline SA-1199B & $1600 \mu \mathrm{g} / \mathrm{mL}$ \\
\hline $05 \mathrm{H}^{* *}$ & $200 \mu \mathrm{g} / \mathrm{mL}$ \\
\hline $09 \mathrm{c}^{* *}$ & $25 \mu \mathrm{gL}$ \\
\hline $02 \mathrm{H}^{* *}$ & $1600 \mu \mathrm{g} / \mathrm{mL}$ \\
\hline $015^{* *}$ & $1600 \mu \mathrm{g} / \mathrm{mL}$ \\
\hline $171 \mathrm{c}^{* *}$ & $1600 \mu \mathrm{g} / \mathrm{mL}$ \\
\hline
\end{tabular}

* effluxing strains

**strains MARSA (methicillin and aminoglycoside resistant Staphylococcus aureus)

This essential oil of Turnera subulata Sm showed effective antibacterial activity for the various strains of $S$. aureus tested, with the MIC values between $25 \mu \mathrm{g} / \mathrm{mL}$ and $1600 \mu \mathrm{g} / \mathrm{mL}$ (Table 2). Really, van Vuuren (2008) has stated that essential oils with a MIC value of $2 \mathrm{mg} / \mathrm{ml}$ or lower could be considered noteworthy.

\section{ACKNOWLEDGEMENTS}

The authors thank to CAPES and CNPQ for financial support.

\section{REFERENCE}

ANTÔNIO, M. A. Ações farmacológicas gerais da Turnera ulmifolia L. sobre a resposta inflamatória. Campinas, SP: [s.n.]. p. Dissertação de Mestrado, Faculdade de Ciências Médicas, Universidade Estadual de Campinas (1996).

Adams, R. P., Identification of Essential Oil Components by Gas Cromatography/Mass Spectroscopy. $4^{\text {th }}$ Ed.,. Allured Publ. Corp, Carol Stream (1995).

ARBO, M. M., Turneraceae, in KUBITZKI, K. (Ed.). The Families and Genera of Vascular Plants 9: 458-466 (2007).

ARBO, M. M., Systematic studies in Turnera (Turneraceae). IV. Series Leiocarpae, Conciliatae and Sessilifoliae. Bonplandia 17: 107-334 (2008).

BARBOSA, D. A., NURIT, K. S., AGRA, M. F., Estudo farmacobotânico comparativo de Folhas de Turnera chamaedrifolia Cambess. e Turnera subulata Sm.. (Turneraceae). Rev Bras Farmacogn 17: 396-413 (2007).

CLSI - Clinical and Laboratory Standards Institute/NCCLS. Performance Standards for Antimicrobial Susceptibility Testing; Fifteenth Informational Supplement. CLSI/ NCCLS document M100-S15. Clinical and Laboratory Standards Institute: Wayne, PA, USA. (2005).

ESSAWI, T. AND SROUR, M., Screening of some Palestinian medicinal plants for antibacterial activity. $J$. 
Ethnopharmacol. 70, 343-349 (2000).

FALCÃO-SILVA, V. S., SILVA, D. A., SOUZA, M. F. V., SIQUEIRA-JUNIOR, J. P., Modulation of drug resistance in Staphylococcus aureus by a kaempferol glycoside from Herissantia tiubae (Malvaceae). Phytother. Res. 23: 1367 - 1370 (2009).

FISHER, K., PHILLIPS, C., Potential antimicrobial uses of essential oils in food: is citrus the answer?. Trends Food Sci. Technol. 19: 156-164 (2008).

FREITAS, F. I. S., Guedes-Stehling, E., SiqueiraJunior, J. P., Resistance to gentamicin and related aminoglycosides in Staphylococcus aureus isolated in Brazil. Lett. Appl. Microbiol. 29: 197-201 (1999).

GIBBONS, S., OLUWATUYI, M., VEITCH, N. C. E., GRAY, A. I., Bacterial Resistance Modifying Agents from Lycopus europaeus. Phytochem. 62: 83-87 (2003).

GONZALES, A. M., ARBO, M. M., Anatomía de algunas especies de Turneraceas. Acta Bot. Venez. 28: 369394 (2005).

HAMMER, K. A., CARSON, C. F., RILEY, T. V., Antimicrobial activity of essential oils and other plant extracts. J. Appl. Microbiol. 86: 985-990 (1999).

KUMAR, S., TANEJA, R., SHARMA, A., Pharmacognostic Standardization of Turnera aphrodisiaca Ward. J. Med. Food 9: 254-260 (2006).

LEWIS, K., AUSUBEL, F. M., Prospects for plant-derived antibacterials. Nat. Biotechnol. 24: 1504 -1507 (2006).

LIMA, E. O., GUERRA, M. F. L., SILVA, M. G., Antimicrobial activity of the essential oil from Turnera ulmifolia L. (Turneraceae). Rev. Bras. Farmacia, 81(3/4), 95-97 (2000).

LOWY, D. F., Antimicrobial resistance: the example of Staphylococcus aureus. J Clin Invest 111: 1265-1273 (2003).

MAIA, J. G. S., ANDRADE, E. H. A., CARREIRA, L. M. M., CONSTITUINTES VOLÁTEIS DE ESPÉCIES AROMÁTICAS DA ILHA DO MARAJÓ - PA. IV Simpósio Brasileiro de Óleos essenciais. Fortaleza, Brasil (2007).

Prabuseenivasan, S., Jayakumar, M., Ignacimuthu S., In vitro antibacterial activity of some plant essential oil. BMC Compl. Alter. Med. 6: 1-8 (2006).

SIQUI, A.C., SAMPAIO, A.L.F., SOUSA, M.C., HENRIQUES, M.G.M.O., RAMOS, M.F.S., Óleos essenciais - potencial antiinflamatório. Biotecnolog. Cienc. desenvolv 16: 38-43 (2000).

SIKKEMA, J., BONT, J. A., POOLMAN, B., Interactions of cyclic hydrocarbons with biological membranes. $J$. Biol. Chem. 18: 8022-8028 (1994).

VAN DER DOOL, H., KRATZ, D. J., A generalization of the retention index system incluing liner temperature programmed gas-liquid partition chromatography. J. Chrom. 11: 463-467 (1963).

VAN VUUREN, S.F. Antimicrobial activity of South African medicinal plants. J. Ethnopharmacol. 119, 462-472 (2008). 